\title{
Energy Storage, Growth, and Maturation of Yellow Perch from Different Locations in Saginaw Bay, Michigan
}

\author{
James S. Diana and Ronald Salz \\ School of Natural Resources and Great Lakes Research Division \\ University of Michigan, Ann Arbor, Michigan 48109-1115, USA
}

\begin{abstract}
The growth and abundance of yellow perch Perca flavescens in Saginaw Bay have varied historically. Changes in growth have been ascribed to many causes, including density and genetic composition of the fish stock, both of which are also believed to vary with location in the bay. The objectives of this study were to compare growth and maturation of yellow perch from inner and outer Saginaw Bay, to investigate the existence of different fish stocks, and to compare growth of yellow perch in Saginaw Bay to growth in other locations to determine the degree of stunting. Yellow perch were collected from four sites in inner and outer Saginaw Bay from 1983 to 1985. Size distributions differed between the inner and outer bay sites: larger and older fish were more common in the outer bay. Percentage of body water, body energy density, gonadosomatic index, and age at maturation did not differ between the inner and outer bay sites. Growth in weight, total body energy, and condition factors differed significantly. These results indicate that growth conditions differ between the inner and outer bay, but the fish populations may not be isolated completely, as has been suggested. Results also suggest that the growth differential has not caused large geographic differences in growth rate, but has caused small condition differences. Yellow perch growth is poor in Saginaw Bay, and the fish appear unable to store substantial energy reserves at any time of year. It appears that behavioral differences between young and old fish may cause the differential distribution of fish by size in Saginaw Bay.
\end{abstract}

The yellow perch Perca favescens is an important sport fish in the Great Lakes and many inland lakes. Historically, yellow perch composed a large portion of the Great Lakes commercial catch, particularly in Saginaw Bay (Lake Huron), Green Bay (Lake Michigan), and Lake Erie. In Lake Huron, $60 \%$ of the commercial catch has been taken from Saginaw Bay (Baldwin and Saalfield 1962), where $100-1,600$ tonnes have been removed per year (Hile and Buettner 1959). Not only have commercial catches varied considerably, but somatic growth of yellow perch has also varied in a density-dependent manner (El Zarka 1959). Rapid growth in the early 1900 s was believed to be due to overexploitation (Hile and Jobes 1941), whereas later declines in growth were attributed to reduced fishing pressure and high densities (El Zarka 1959). The current high abundance of small yellow perch in Saginaw Bay has raised many complaints from users. Sport anglers are now the major consumers of yellow perch; commercial fishing is extremely limited due to large minimum-size limits and restrictive quotas. In general, changes in density, growth rate, and reproductive success of yellow perch populations have been attributed to variations in water temperature (Eshenroder 1977), storms (Busch et al. 1975), interspecific competition (Regier et al. 1969), stunting (Persson 1983), and overfishing (El Zarka 1959).
The inner portion of Saginaw Bay receives water from waste outfalls of major industries and has a history of widespread pollution (Eshenroder 1977). It is very shallow, eutrophic, and has an average depth of $4.6 \mathrm{~m}$. The outer bay, the area east of Sand Point and Point Lookout (Figure 1), is much less eutrophic and thus similar to Lake Huron proper, and has an average depth of 15.6 $m$. If yellow perch show limited movements within Saginaw Bay, then they may actually exist in two very different ecosystems.

Fish populations often show extreme variation in growth and mortality rates, and are prone to stunting (Burrough and Kennedy 1979; Linfield 1979). Stunting is a process characterized by poor growth and early age at maturation (Alm 1946; Spangler et al. 1977), and may result from competition (Persson 1983), poor temperature conditions (Diana 1987), or physiology (Fryer and Bern 1979). Because both somatic and reproductive energy allocations differ between sexes for many fish (Diana and Mackay 1979), the degree of stunting also may differ by sex. Studies on stunting of fish have been relatively limited, but slow growth, convergent growth of older age-classes, and early maturation all indicate stunting. Slow growth can be inferred from several measurements, including length at age, weight at age, and energy content of individuals of an age-class over 


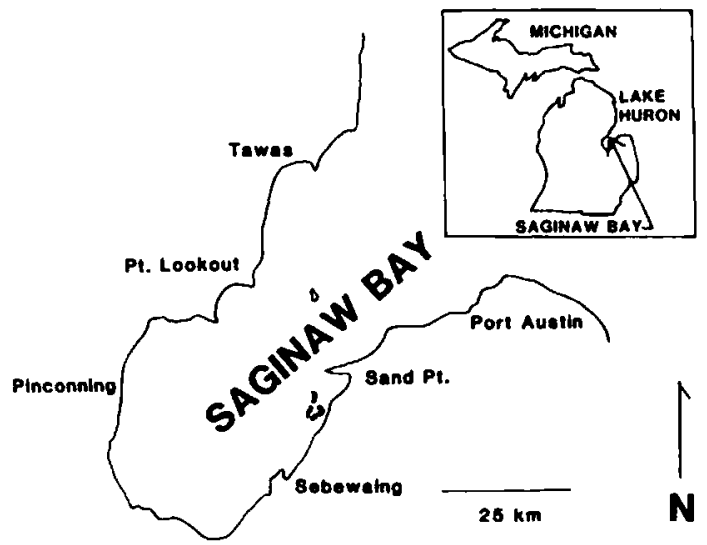

Figure 1.-Collection sites for yellow pench in Saginaw Bay, Michigan. Point Lookout and Sand Point mark the boundary between the inner and outer bay.

time. Limited energy storage can be indicated by inability to accumulate significant lipid reserves over growth periods. Changes in lipid content can be measured directly, or indirectly by changes in energy equivalents (kilojoules per gram dry weight) or percentage of water, both of which are correlated with lipid content (Shul'man 1974).

Historical data for Saginaw Bay indicate the existence of larger yellow perch in the outer bay and smaller ones in the inner bay. It has been suggested that these populations are differentiated by spawning origin. Outer bay yellow perch may originate from a riverine stock, while inner bay fish may be derived from a lacustrine stock (Spangler et al. 1977). The existence of two unique stocks has never been confirmed, and widespread pollution in local rivers may have reduced or eliminated any riverine stock (Eshenroder 1977). Spangler et al. (1977) reviewed the literature, which indicated sympatric, fast- and slow-growing groups of Perca spp. in many water bodies, and implied genetic and behavioral differences between these groups. Riverine stocks of percids are believed to produce larger fish at maturity (Bailey and Gosline 1955) that spawn earlier in each season (Nelson and Walburg 1977) in colder, flowing waters of rivers (Chikhova 1973). They may also have distinctive morphometric characteristics (Chikhova 1973). If larger yellow perch from the outer bay represent such a riverine stock, one might hypothesize that these fish would grow more rapidly or mature later in life than inner bay fish, two characteristics that are the opposite of stunting.

Hayward and Margraf (1987) found that differences in the size distribution of yellow perch in
Lake Erie were due to growth differences caused by limited movements and differential availability of food in the central and western basins. Because Saginaw Bay is an open system, and intermixing of yellow perch between the two locations is possible, the existence of larger yellow perch in the outer bay may also be due to similar factors, for example, a faster growth rate, a lower mortality rate, or movement of older fish from the inner to outer bay.

The goal of this study was to determine if the different size structures of inner and outer bay yellow perch populations were present in the 1980 s, and if so, to evaluate whether the size differential was due to differential growth and maturation between the two localities. Our specific objectives were (1) to compare annual and seasonal body growth and somatic energy reserves for both sexes of yellow perch from inner and outer Saginaw Bay; (2) to compare age at maturation and gonadosomatic index for yellow perch from the two sites to evaluate whether location affected differential reproductive allocations; and (3) to compare growth of yellow perch in Saginaw Bay to growth in other localities to determine the degree of stunting in the yellow perch population.

\section{Methods}

Yellow perch were sampled from four sites in Saginaw Bay (Figure 1). Tawas and Port Austin represented the outer bay; Sebewaing and Pinconning represented the inner bay. Collections were made with experimental gill nets (7.6-m lengths; $1.3,1.9,2.5,3.8,5.1$, and 6.4-cm stretch mesh). Sampling began on 15 May 1983 and concluded on 25 February 1985. Nets were set for 3-12 h, and all fish were frozen upon collection and held at $-30^{\circ} \mathrm{C}$ for later analysis. Collections were made nearly monthly in the summer and sporadically during the winter (Table 1). All four sites were sampled during each collection period, except during winter, when irregular ice distribution limited sampling effort and location.

Fish were measured (total length, $\mathrm{mm}$ ), and weighed (wet weight, $g$ ). Scales were removed from the left side of the fish, at the termination of the pectoral fin and below the lateral line, and later read to determine age. At least four scales per fish were analyzed. Age determinations were verified by two other experienced persons who checked $5 \%$ of the scales (R. Salz and W. Bryant, Michigan Department of Natural Resources). Attempts to validate aging by recapture of previously sampled 
Table 1. -Number of yellow perch $(N)$ taken from Saginaw Bay, 1983-1985.

\begin{tabular}{clr}
\hline Month and year & \multicolumn{1}{c}{ Site } & $N$ \\
\hline Jun 1983 & Tawas & 111 \\
& Pinconning & 60 \\
& Sebewaing & 136 \\
& Port Austin & 94 \\
Jul 1983 & Tawas & 79 \\
& Pinconning & 56 \\
& Sebewaing & 77 \\
& Port Austin & 52 \\
Aug 1983 & Tawas & 66 \\
& Pinconning & 142 \\
& Sebewaing & 100 \\
& Port Austin & 78 \\
Feb 1984 & Tawas & 8 \\
& Pinconning & 3 \\
& Sebewaing & 14 \\
Apr 1984 & Tawas & 81 \\
& Pinconning & 91 \\
& Sebewaing & 100 \\
& Port Austin & 34 \\
Jun 1984 & Tawas & 65 \\
& Pinconning & 76 \\
& Sebewaing & 61 \\
& Port Austin & 100 \\
& Tawas & 45 \\
& Pinconning & 83 \\
& Sebewaing & 101 \\
& Port Austin & 56 \\
& Tawas & 56 \\
& Pinconning & 41 \\
\hline & &
\end{tabular}

fish were unsuccessful due to low return rates (only four scale sets for 4,280 tagged and released fish).

All fish were dissected and visually identified to sex. Gonad weight was measured to 0.01 g. A random subsample of five fish per sex and size-group $(2.5 \mathrm{~cm})$ was taken for further analysis when possible. The body of each fish was either dried whole or pulverized in a food processor, subsampled, and dried. Body and gonad tissues were dried at $80^{\circ} \mathrm{C}$ to constant weight and weighed to $0.01 \mathrm{~g}$. Dried tissues were then pulverized in a coffee mill. Percentage of body water was calculated from changes in the whole or subsampled body during drying. Body dry weight (without gonads) was calculated

$$
\text { body wet weight }\left(\frac{(1-\text { percentage of body water }}{100}\right) \text {. }
$$

The gonadosomatic index was calculated as the percentage ratio of gonad wet weight to the total body wet weight for each yellow perch. Body energy values and gonadosomatic indexes were determined only for 2-4-year-old fish, due to low sampling frequencies of other age-classes. Maturity stages were not measured directly, but a fish was assumed to be mature if its gonadosomatic index was greater than 2\% in February (Le Cren 1951). A subsample of 132 fish that were collected from all sites in June-August was used in calorimetric analysis. Body joules per gram dry weight (energy equivalent) were determined with a microbomb calorimeter and standard methods (Paine 1971). Only one analysis was done per sample, because this method is very repeatable (coefficient of variation for standards $<1 \%$ ). Total body energy (without gonads) was determined for these fish by multiplying body dry weight by the energy equivalent for each fish.

Differences between sites, seasons, sexes, or ageclasses were tested with analysis of variance (ANOVA). Multiple-regression analysis was used to compare total body energy to total length, body wet weight, percentage of body water, and energy equivalent to determine which variables were important in explaining total body energy. Regression analysis was used to assess size- or age-related trends. Chi-square tests were used to assess the differences in age or size at maturation and age or size frequency among sites. Finally, differences in regressions between sexes or sites were tested by analysis of covariance (ANCOVA). All statistics were calculated with the Michigan Interactive Data Analysis System (Fox and Guire 1976), with significance set at $P \leq 0.05$.

\section{Results}

The size distribution of yellow perch differed significantly $(P<0.001)$ between outer and inner bay sites; the outer bay sites had a higher proportion of large fish than the inner bay sites (Figure 2). This trend agreed with the historical data on size differences between these sites. The size distributions were also complemented by differential age distributions (Figure 2), which indicated that older fish were also more common in the outer bay.

Females grew significantly faster than males in length (ANCOVA, $P=0.002$; Figure 3), but there was no significant difference in the slopes of length at age between inner and outer bay sites for either males $(P=0.53)$ or females $(P=0.97)$. Growth rates appeared to accelerate at older ages in the outer bay, but these ages were poorly represented in inner bay samples.

Unlike changes in total length, growth in weight differed significantly between inner and outer bay sites as well as between sexes. As we expected, growth of yellow perch did not differ between sites within the inner or outer bay $(P>0.05)$; thus, we combined data by inner or outer bay for further 

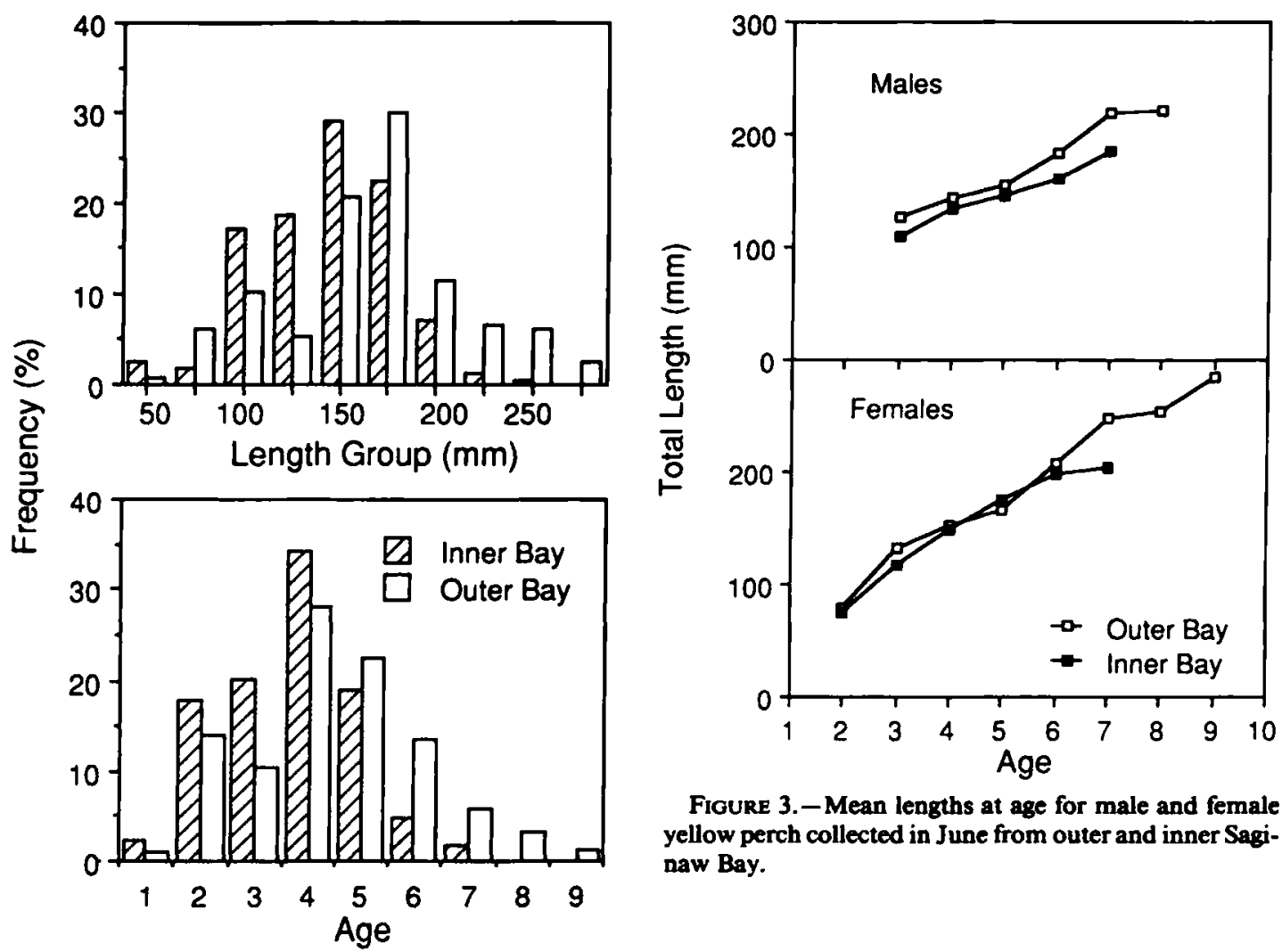

FIGURE 2.-Total length-group (25-mm increments) and age-group frequencies for yellow perch collected from inner and outer Saginaw Bay, 1983-1984.

analyses. Because the dynamics of growth were assumed to be influenced by food abundance or fish density, we expected no difference in weight at age for a sex and year-class in different years. There were no significant differences in weight at age between years for males or females $(P>0.05)$ so results from each year were combined by month (sexes separate) to increase monthly sample size for further analyses. Exponents of length-weight relationships differed significantly between inner and outer bay; outer bay fish were heavier at any length than inner bay fish of the same sex.

The percentage of body water did not differ significantly between sexes for most months or yearclasses $(P>0.05)$. There were also no significant differences in percentage of water between fish from inner or outer bay sites (ANOVA, $P>0.05$ ). Therefore, sexes and sites were combined to evaluate age and time effects. For all months, there was a significant negative correlation between water percentage and age $(P<0.001)$, suggesting an accumulation of lipid reserves with age. Water

Figure 3.- Mean lengths at age for male and female yellow perch collected in June from outer and inner Saginaw Bay.

percentage was lowest in late fall and highest in spring for all age-classes (Figure 4), although absolute changes were small.

Body energy equivalents were significantly correlated with weight $\left(r^{2}=0.11, P=0.0001\right)$, and there were significant increases in body energy equivalents with age (ANOVA, $P<0.01$ ). There was no significant difference between sexes in body energy equivalents, nor were there any differences

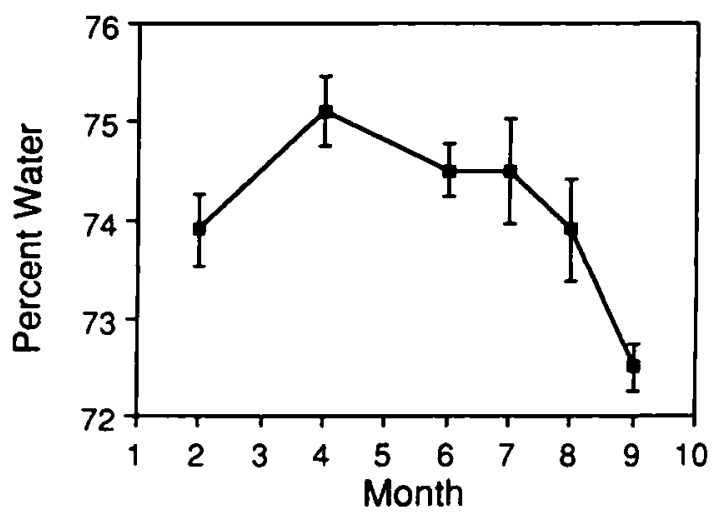

FIGURE 4.-Monthly changes in percentage of body water (mean $\pm 95 \%$ confidence limits) for yellow perch from Saginaw Bay. January is month 1. 
among months (June, July, or August). In general, yellow perch showed similarity among sites and sexes in body energy equivalents. The one exception was at Tawas in the outer bay, where yellow perch had a slightly higher mean body energy equivalent than fish at the other three sites $(20.3$ $\mathrm{kJ} / \mathrm{g} \pm 0.9 \mathrm{SD}$ for Tawas, $19.1 \pm 0.9$ for the other three sites). This may reflect the higher frequency of large yellow perch that we collected at Tawas, because body energy equivalents increased with size and age.

In order to estimate total body energy for all fish, we performed a multiple regression between total body energy for each fish subjected to calorimetry $(N=132)$ and total length, wet body weight, percentage of body water, and body energy equivalent. This regression included all variables $\left(R^{2}=0.99\right)$, but most predictability was due to wet weight. Because wet body weight was directly measured for all fish, total body energy for all fish was calculated from the regression $\left(r^{2}=0.94\right)$

$$
Y=5.73 X-36.8 \text {; }
$$

$Y=$ total body energy $(\mathrm{kJ}) ; X=$ wet body weight (8).

Yellow perch from the outer bay generally showed significantly higher total body energy for each age and month than did yellow perch from the inner bay. Of 36 possible ANOVAs for differences in total body energy between sites ( 2 sexes, 3 ages, 6 months), 11 indicated significantly greater energy in outer bay fish and 2 in inner bay fish; 15 comparisons showed no differences between sites and 8 comparisons could not be made because of insufficient data. Females usually had significantly higher total body energy contents than males for each age, site, and month (12 ANOVA pairs showed females with significantly higher total body energy contents; 15 were not significant; 9 had insufficient data to test). Yellow perch showed increases in total body energy over the summer (April-September) for all ages and sites (Figure 5). Smaller increases in body energy also occurred from late fall to winter, and energy depletion occurred in early spring (spawning time).

There were no significant differences in size or age at maturation between fish from inner and outer bay sites (chi-square test, $P>0.05$ ), although small sample sizes made some comparisons difficult. Overall, males were mature by age 2 , whereas only $20 \%$ of females were mature by age $2,72 \%$ by age 3 , and $100 \%$ by age 4 . All males between 100 and $135 \mathrm{~mm}$ total length in February were mature; only $28 \%$ of females were mature at

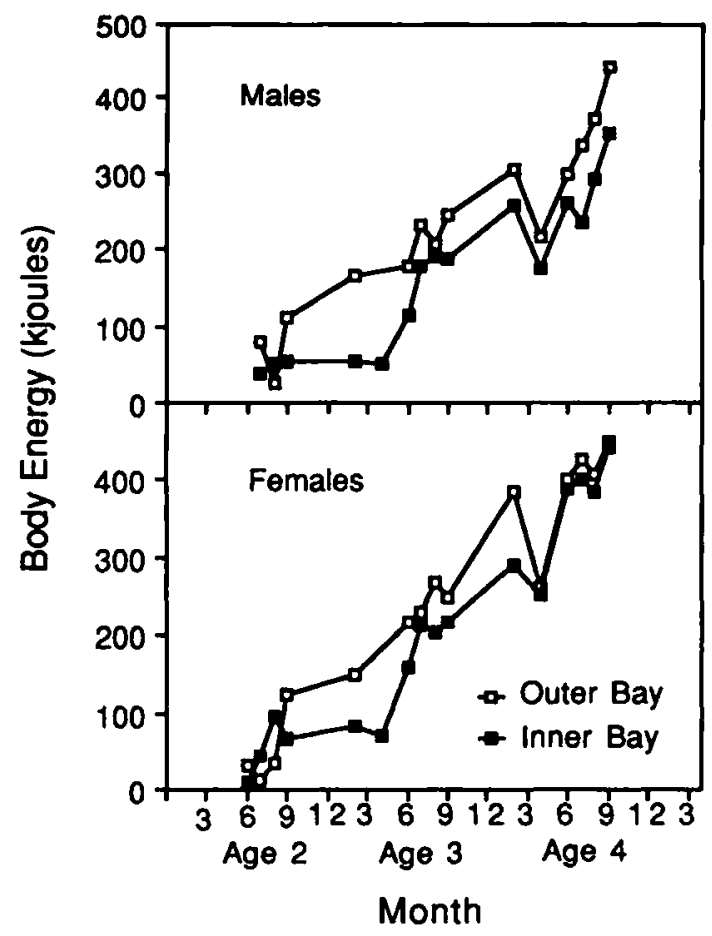

FIGURE 5. - Seasonal changes in total body energy for three age-classes of male and female yellow perch from inner and outer Saginaw Bay.

this size. A high percentage (92\%) of the females collected in February were mature at total lengths of $140 \mathrm{~mm}$ or greater.

There were no significant differences in gonadosomatic indexes between inner and outer bay sites for any sex or age-class of mature fish. The gonadosomatic indexes of mature males and females increased significantly with age and were considerably higher for mature females than for mature males, especially at age 4 (Figure 6). Gonad growth occurred mainly in August for males of all ages; female gonad growth began in August and continued over winter. Spawning occurred in late April to May, and recrudescence of gonads occurred in both sexes over the summer.

\section{Discussion}

Yellow perch from inner and outer Saginaw Bay differed considerably in several population characteristics, but only slightly in growth dynamics. The outer bay fish had a greater frequency of larger and older individuals and a slightly greater weight and body energy content at each age. However, length at age did not differ significantly between sites. A significantly different length-weight rela- 


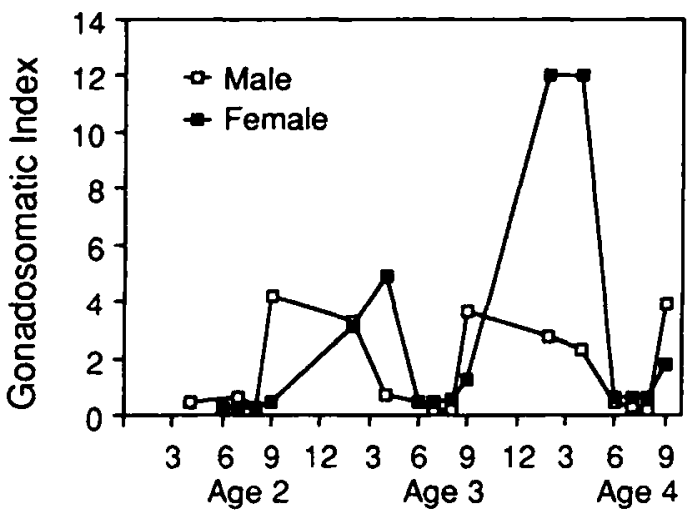

Month

FIGURE 6.-Seasonal changes in the gonadosomatic index of each sex and age-class of yellow perch from Saginaw Bay.

tionship resulted in significant weight-at-age differences between inner and outer bay fish. Weight at a given length is often used as an indicator of condition (Anderson and Gutreuter 1983). Although yellow perch in the outer bay apparently had a better growth environment than fish in the inner bay, this did not influence the lifetime pattern of growth in length. Weight-at-age differences between fish in the inner and outer bay were most likely due to differences in temperature or food availability that gave outer bay fish a temporary or slight growth advantage.

Fish from inner and outer bay sites did not differ in maturation times or gonadosomatic indexes. These observations, coupled with the limited growth differences between sites, lead us to speculate that there are not major genetic or ecological differences between fish in the inner and outer bay. While this does not disprove the hypothesis of genetic isolation, the degree of differentiation in growth and maturation between inner and outer bay fish is not comparable in magnitude to the lange degree of differentiation between riverine and lacustrine stocks that Spangler et al. (1977) proposed for growth and maturation.

Large differences were not observed among sites in energy equivalents for yellow perch, nor were there any significant seasonal trends. Apparently, the changes in growth and energy depletion that occurred with season and location resulted from use of whole tissue (including protein and membrane lipids) rather than specific constituents, such as lipid or protein, that would alter the energy equivalent (Brett and Groves 1979). While energy equivalents were only measured for summer samples, percentage of body water, which is usually negatively correlated with lipid content, also varied little over the year. This also suggests seasonal use of whole-body energy reserves rather than just lipids. The use of whole tissue for energy reserves may indicate poor growth conditions for yellow perch in Saginaw Bay, because the fish were apparently unable to store significant lipid reserves over the summer. This contrasts with several other studies of yellow perch that showed large seasonal patterns of lipid storage and depletion (Makarova 1973; Craig 1977). However, somatic energy reserves, measured in body energy equivalents, did increase with age for yellow perch in our study. This may indicate that conditions (e.g., food availability or particle size) for yellow perch growth improved with age; other fish populations have been reported to accumulate more energy reserves with age (Shul'man 1974).

Growth of yellow perch also differed by sex; females grew more rapidly in total length and energy and also allocated more energy to gonad production. Somatic growth occurred mainly in the early summer; gonad growth occurred in late summer and winter. Both of these patterns have also been found in other yellow perch populations (LeCren 1951; Makarova 1973; Craig 1977; Tanasichuk 1978). The winter growth observed in this study may have been actual or the result of limited winter samples.

Overall, fish from the inner and outer bay had a very slow growth rate. A comparison to other yellow perch populations (Figure 7) indicated extremely poor growth in Saginaw Bay. Criteria for stunted populations differ by author, but include two concepts: (1) growth considerably below a regional average, and (2) convergence of several older age-classes towards a similar size. There is no evidence that older fish reached a similar size in Saginaw Bay (Figure 7), although growth was much below the state average. We conclude that yellow perch in Saginaw Bay are stunted, based on their slow growth and early reproduction schedules.

In this study, we assumed no size-related mortality within age-classes, because growth rate was measured by changes in average size of individuals in a cohort. We have no direct evidence to support this assumption. Any size-related mortality probably did not influence comparisons among sexes or sites very much, because the same biased mortality likely occurred for both sexes or at both sites. Also, most comparisons were made on age- 2 to age- 4 fish, whereas it is most likely 


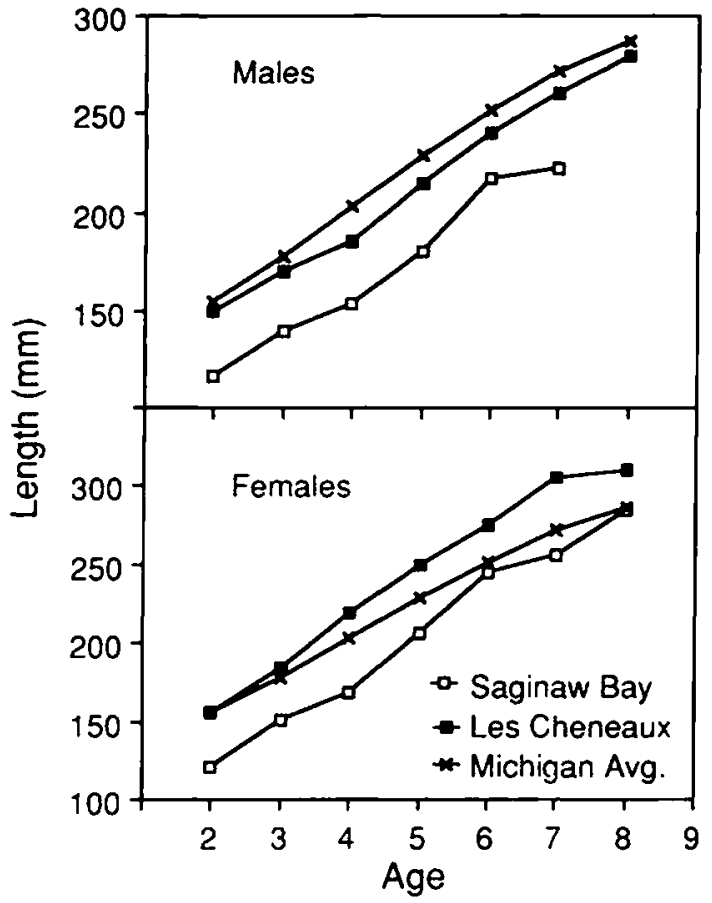

FIGURE 7.-Comparative lengths at age for male and female yellow perch from Saginaw Bay, the Les Cheneaux Islands in northem Lake Huron (Lucchesi 1988), and the Michigan state average (Laarman et al. 1981). Fish for the Michigan average were not separated by sex.

that natural mortality would be size-related for age-0 and age-1 fish (Forney 1971). If size-selective mortality exists, it could affect comparisons of this fish population with others.

Because size was compared over time, gear selectivity could also bias these data. Gill nets are generally considered to be size-selective in capture efficiency (Hubert 1983). However, the experimental gill nets we used for yellow perch do not appear to be very size-selective compared to trawls (R. Haas, Michigan Department of Natural Resources, personal communication). Most selectivity for experimental gill nets likely occurs among young fish, which can pass through the nets. Only larger fish were compared in this study, so we assumed that net selectivity did not bias our seasonal or age-related analyses.

The yellow perch population we found in Saginaw Bay was very similar in size structure and growth rate to that of the early 1950s (El Zarka 1959). At that time the population was believed to be stunted due to overpopulation and competition related to low fishing pressure (Eshenroder 1977). Recent sport and commercial catches in
Saginaw Bay (Ryckman 1986) have been considerably higher than commercial yields in the 1950 s (520 tonnes/year recently, versus 175 tonnes/year in the 1950s; Hile and Buettner 1959). This level of exploitation is similar to average historical yields (450 tonnes/year), and could indicate fairly normal exploitation rates. Thus, the current limitation on yellow perch growth may not be due to high fish densities, but rather to low food availability.

The differential size distribution between inner and outer bay fish did not reflect the level of differentiation expected between riverine and lacustrine stocks. Size-related differences in behavior could cause the age structure noted, or the results could be due to differential fishing pressure between sites. We favor the former explanation for the following reasons. Spawning sites are predominantly located in the inner bay (Goodyear et al. 1982), and most fish apparently move there to spawn. As fish get larger, they may be able to move further from spawning sites during summer foraging and occasionally encounter better food resources in the outer bay. As they return to the inner bay to spawn, they may intermix with fish that spent the summer at other sites. This behavior would produce the large variation in size at age that was present in our data. We have done tagging studies to determine movement patterns of yellow perch within Saginaw Bay. Our results in general agree with the above speculation, but tag returns have been insufficient to prove statistically prove that age-related differences exist in the movement patterns of this species.

\section{Acknowledgments}

We thank S. Braden, B. Diana, R. Haak, S. Latta, D. Ottey, C. Pickett, J. Schaeffer, and P. Seelbach for their help; G. Fowler aided in statistical interpretation. This publication is the result of work sponsored by the Michigan Sea Grant College Program, under grant NA-80AA-D-0072, project R/GLF-17, from the National Oceanic and Atmospheric Administration, U.S. Department of Commerce, and by funds from the state of Michigan. This is contribution 535 of the Center for Great Lakes and Aquatic Sciences, University of Michigan.

\section{References}

Alm, G. 1946. Reasons for the occurrence of stunted populations with special reference to perch. Institute of Freshwater Research Drottningholm Report 25. 
Anderson, R. O., and S. J. Gutreuter. 1983. Length, weight, and associated structural indices. Pages 283300 in L. A. Nielsen and D. L. Johnson, editors. Fisheries techniques. American Fisheries Society, Bethesda, Maryland.

Bailey, R. M., and W. A. Gosline. 1955. Variation and systematic significance of vertebral counts in the American fishes of the family Percidae. Miscellaneous Publications of the Museum of Zoology, University of Michigan 93:1-44.

Baldwin, N. S., and R. W. Saalfield. 1962. Commercial fish production in the Great Lakes 1867-1960. Great Lakes Fishery Commission Technical Report 3.

Brett, J. R., and T. D. D. Groves. 1979. Physiological energetics. Pages 279-352 in W. S. Hoar, D. J. Randall, and J. R. Brett, editors. Fish physiology, volume 8. Academic Press, New York.

Burrough, R. J., and C. R. Kennedy. 1979. The occurrence and natural alleviation of stunting in a population of roach, Rutilus rutilus (L.). Journal of Fish Biology 15:93-110.

Busch, W. D., R. L. Scholl, and W. L. Hartman. 1975. Environmental factors affecting the strength of walleye (Stizostedion vitreum vitreum) year classes in western Lake Erie, 1960-1970. Journal of the Fisheries Research Board of Canada 32:1733-1743.

Chikhova, V. M. 1973. Local populations of perch (Perca fuviatilis L.) in Kuybyshev Reservoir. Journal of Ichthyology 13:491-496.

Craig, J. F. 1977. The body composition of adult perch, Perca fluviatilis, in Windermere, with reference to seasonal changes and reproduction. Jounal of Animal Ecology 46:617-632.

Diana, J. S. 1987. Simulation of mechanisms causing stunting in northern pike populations. Transactions of the American Fisheries Society 116:612-617.

Diana, J. S., and W. C. Mackay. 1979. Timing and magnitude of energy deposition and loss in the body, liver, and gonads of northern pike (Esox lucius). Journal of the Fisheries Research Board of Canada 36:481-487.

El Zarka, S. 1959. Fluctuations in the population of yellow perch, Perca flavescens (Mitchill), of Saginaw Bay. U.S. Fish and Wildlife Service Fishery Bulletin 59:365-415.

Eshenroder, R. L. 1977. Effects of intensified fishing, species change, and spring water temperatures on yellow perch. Perca flavescens, in Saginaw Bay. Journal of the Fisheries Research Board of Canada 34:1830-1838.

Forney, J. L. 1971. Development of dominant year classes in a yellow perch population. Transactions of the American Fisheries Society 100:739-749.

Fox, D. J., and K. E. Guire. 1976. Documentation for MIDAS. Statistical Research Laboratory, University of Michigan, Ann Arbor, Michigan.

Fryer, J. N., and H. A. Bern. 1979. Growth hormone binding to tissues of normal and stunted juvenile coho salmon, Oncorhynchus kisutch. Journal of Fish Biology 15:535-544.

Goodyear, C. D., T. A. Edsall, G. D. Moss, and P. E. Polanski. 1982. Atlas of spawning and nursery ar- eas of Great Lakes fishes. U.S. Fish and Wildlife Service FWS/OBS-82/52.

Hayward, R. S., and F. J. Margraf. 1987. Eutrophication effects on prey size and food availability to yellow perch in Lake Erie. Transactions of the American Fisheries Society 116:210-223.

Hile, R., and H. J. Buettner. 1959. Fluctuations in the commercial fisheries of Saginaw Bay 1885-1956. U.S. Fish and Wildlife Service Research Report 51.

Hile, R., and F. W. Jobes. 1941. Age, growth, and reproduction of the yellow perch, Perca flavescens (Mitchill), of Saginaw Bay. Transactions of the American Fisheries Society 70:102-122.

Hubert, W. A. 1983. Passive capture techniques. Pages 95-1 22 in L. A. Nielsen and D. L. Johnson, editors. Fisheries techniques. American Fisheries Society, Bethesda, Maryland.

Laarman, P. W., J. C. Schneider, and H. Gowing. 1981. Methods in age and growth analyses of fish. Pages VI-A-4-I to VI-A-4-17 in J. W. Merna, J. C. Schneider, G. R. Alexander, W. D. Alward, and R. L. Eshenroder, editors. Manual of fisheries survey techniques. Michigan Department of Natural Resources, Fisheries Management Report 9, Ann Arbor.

Le Cren, E. D. 1951. The length-weight relationship and seasonal cycle in gonad weight and condition in the perch (Perca fluviatilis). Journal of Animal Ecology 20:201-219.

Linfield, R. S. J. 1979. Changes in the rate of growth in a stunted roach Rutilus rutilus population. Journal of Fish Biology 15:299-308.

Lucchesi, D. O. 1988. A biological analysis of the yellow perch population in the Les Cheneaux Islands, Lake Huron. Master's thesis. University of Michigan, Ann Arbor.

Makarova, N. P. 1973. Seasonal changes in some of the physiological characteristics of the perch (Perca fuviatilis L.) of Ivan'koko Reservoir. Journal of Ichthyology 13:742-752.

Nelson, W. R., and C. H. Walburg. 1977. Population dynamics of yellow perch (Perca flavescens), sauger (Stizostedion canadense), and walleye ( $S$. vitreum vitreum) in four mainstem Missouri River reservoirs. Journal of the Fisheries Research Board of Canada 34:1748-1763.

Paine, R. T. 1971. The measurement and application of the calorie to ecological problems. Annual Review of Ecology and Systematics 2:145-164.

Persson, L. 1983. Food consumption and competition between age classes in a perch Perca fluviatilis population in a shallow eutrophic lake. Oikos 40:197207.

Regier, H. A., V. C. Applegate, and R. A. Ryder. 1969. The ecology and management of the walleye in western Lake Erie. Great Lakes Fishery Commission Technical Report 15.

Ryckman, J. R. 1986. A creel survey of sportishing in Saginaw Bay, Lake Huron, 1983-84. Michigan Department of Natural Resources, Fisheries Division, Technical Report 86-4, Ann Arbor. 
Shul'man, G. E. 1974. Life cycles of fish. Wiley, New York.

Spangler, G. R., N. R. Payne, J. E. Thorpe, J. M. Byrne, H. A. Regier, and W. J. Christie. 1977. Responses of percids to exploitation. Journal of the Fisheries Research Board of Canada 34:1983-1988.
Tanasichuk, R. W. 1978. Characteristics of body and gonad growth of yellow perch, Perca Ravescens, from Lac Ste. Anne, Alberta. Master's thesis. University of Alberta, Edmonton.

Received November 15, 1989 Accepted April 20, 1990 